\title{
The Effect of Problem Based Learning Instruction on Students Science Process Skills in Physics
}

\author{
Pratiwi Sri Wardani \\ Universitas Mulawarman Samarinda \\ Samarinda \\ wardani_pratiwisri@yahoo.com
}

\begin{abstract}
This research was aimed to examine how problem based learning model of instruction related to junior high students' science process skills in physics. The data were taken from eight students of the eight grade selected randomly. To control other variables and to ensure that the problem based learning was the only variable affecting students' process skills. A group was used. This group was initially given a pretest of science process skills. This pretest examined the science process skills of students in identifying problem, formulating a hypothesis, identifying independent, dependent, and control variables, planning an experiment, performing the experiment, analyzing data, and making conclusion. This group was then given problem based learning of instruction using the topic of force; and eventually was given a posttest concerning those students' science process skills. A paired test used to analyze the data showing that the problem based learning instruction increased significantly and affected the students' science process skills.
\end{abstract}

Keywords_Problem Based Learning, Science Process Skills

\section{INTRODUCTION}

Students who really want to master science well should first understand the nature of science; otherwise, they will fail to do so. Why is it important for students to understand the nature of science? Understanding of the nature of science is an important goal for education because it can increase students interest, develop awareness of the impact of science in society, and help student develop accurate views of what science is [1].

Science can be expressed in three ways: science as a product, science as a process, and science as an attitude. Consequently, the lack of failure to understand these may cause failure in understanding of what science is.There are some evidence why students do not understand the nature of science. Research studies revealed that the nature of science has not been well transferred yet by teachers. A study on how students defined science was held by NRC (1996) showing that students viewed science primarily as a knowledge to be studied and learned; they lack incomplete views of the science as processes. These views of science by students are understood since literature showed evidence that this aspect of science is most often ignored by school curricula and least understood by students [1]. Another evidence, an investigation of instruction on scientific literacy held by Mitman, et al. (1987) in [1] revealed that 11 seventh-grade life science teachers in the study rarely or never used the contexts of science. Students perception data showed that they viewed science as factual content from the predominant explanation for teachers' instruction [1].

Additionally, research done by [2] also implied that science as process was not well comprehended by the students. This domain of science is poorly addressed in the majority of curricular materials, and when it is addressed it is often misrepresented [2]. While another study done by [1] revealed that the nature of science was not always being directly transferred to students either by the curriculum or by the teachers. When students performed several experiments, they were not told neither by written text or teacher that this was a process used by scientists to produce scientific knowledge. Therefore, students would seperate dimensions of the nature of science and they would not be able to make the connections among these.

Besides, students failure on understanding the nature of science may root from these: first, they do not comprehend many technical terms not associated with any experience accessible to students, and second because the material is presented by teacher too rapidly and too great a volume for understanding of ideas, concepts, or theories; third, most science textbooks focused on processes of testing theories, not on the processes which generated this knowledge.

From the description above, it can be concluded that textbooks expositions and science teacher behaviors are not aligned with the nature of science as the two most obvious sources for student misconceptions about the nature of science. Science textbooks and even the 'newer' curricula, with few exceptions, do not deal with the relationship among scientific explanations and contain statements that portray science as consisting of unalterable, fixed truths [1]. Rather than helping students to develop meaningful understanding about scientific knowledge and the conditions by which it develops, science text materials contribute to the development of student view that scientific knowledge is an array of unconnected facts and concepts [1].

From these evidence, we summarize that traditional education fails in attaining the education needs for the current generation of students. However, this traditional or expository method has been used for many years and is still the prevalent method of teaching science classes. Research studies in this 
area have found that this method is highly inadequate. Largely dependent on textbased, content aquisition and passive flow of fragmented concepts from the teacher to students, this method is widening the gap between valuable learning experiences and the mere compliance of the academic exercise.

As a matter of fact, science teachers have an opportunity to teach students how science makes the world work. Unfortunately, reducing the teaching budgets and being apathy sometimes makes it difficult to get students' interest in the topics like biology, earth science, anatomy, physics, and chemistry. Teachers should use techniques such as peer learning, role playing, and incorporating current events in science lesson plans. These techniques can help engage students and make them understand the importance of science. They will also make teaching scientific concepts more fun and help students understand common topics in scientific world.

Current reforms in science education emphasize teaching science for all, with the ultimate goal of developing scientific literacy. Science, as an academic discipline involves learning the key concepts, as well as the processes of science. Accordingly, it is important for students to learn science process skills. The increased importance of science process skills of students poses a serious challenge of finding ways to improve teaching as a means of elevating the educational outcomes. Interest in developing thinking skills has encouraged added emphasis on process skills instruction. In this view, science instruction must go beyond simply teaching science as a body of knowledge. Today's teachers should be challenged to engage students in a broader view of science ( $\mathrm{NRCl}, 1996)$. In other words, science teachers are increasingly being encouraged and required to teach about the nature of science [2]. Besides, science educators have related teaching about the nature of science to increased students' interest [2].

One of the instruction models using science process skills is Problem Based Learning (PBL). In Phase 3 of PBL, it is stated that teacher's activity is to help students perform an experiment. In this activity students are trained to do the activities of identifying problem, hypothesizing, identifying variables, defining variables, performing experiments, analyzing data, and drawing conclusions. The use of problem based learning approach is viewed as an alternative to deal with this educational need [3].

The aims of this research are to describe the profile of students science process skills of junior high school students before and after participating in learning by using PBL.

\section{REVIEWING LITERATURE}

\section{A. Definition of Science}

Science is a human activity through which problems and questions dealing with natural phenomena can be identified and defined, and solutions proposed and tested, or science is a human activity, a process used to investigate natural phenomena, a process used to add an existing knowledge base, and a social enterprise [1]. On the other hand, Sutrisno (2006) defined science as a body of knowledge, a way of thinking, a way of investigating. Other terms are also used to describe that science is a product (knowledge), an attitude (a way of thinking), and a process (a way of investigation).

\section{B. The Nature of Science}

Three principle components of the nature of science that were defined by the National Council on Science and Technology Education are:

1) Scientific world view: the world is understandable, scientific ideas are subject to change, scientific knowledge is durable, and science cannot provide answers to all questions.

2) Scientific methods of inquiry: science demands evidence, science is a blend of logic and imagination, science explains and predicts, scientists try to identify and avoid bias, and science is not authoritarian, and

3) Nature of the scientific enterprise: science is a complex social activity, science is organized into content disciplines and is conducted in various institutions. There are generally accepted ethical principles in the conduct of science, and scientists participate in public affairs both as specialists as citizens.

On the other hand, the nature of science as identified by educators are three domains of science that are critical to develop scientific literacy (ability to understand media accounts of science to recognize and appreciate the contributions of science, and to be able to use science in decision-making on both everyday and socio-scientific issues). The first of these is the body of scientific knowledge. Of the three, this is the most familiar and concrete domain, and includes the scientific facts, concepts, theories, and laws, typically presented in science textbooks. Scientific methods and processes comprise the second domain, which describes the wide variety of methods that scientists use to generate the knoewledge contained in the first domain. Science curricula delve into this domain when they address process skills and scientific methodology [2].

The nature of science constitutes the third domain and is by far the most abstract and least familiar of the three. This domain seeks to describe the nature of the scientific enterprise, and the characteristics of the knowledge it generates. This domain of science is poorly addressed in the majority of curricular materials, and when it is addressed it is often misrepresented [2]. The nature of science can be represented in the diagram below.

\begin{tabular}{|c|c|}
\hline Science is: & $\begin{array}{c}\text { A Body of Knowledge: } \\
\text { Facts, Definitions, Concepts } \\
\text { Theories, Laws, Etc. }\end{array}$ \\
$\begin{array}{c}\text { A Set of Method/Process } \\
\text { Observing } \\
\text { Estimating } \\
\text { Infering } \\
\text { Predicting } \\
\text { Classifying } \\
\text { Hypothesizing } \\
\text { Experimenting } \\
\text { Concluding } \\
\text { Etc. }\end{array}$ & $\begin{array}{c}\text { A Way of Knowing: } \\
\text { Scientific knowledge is based } \\
\text { upon evidence. } \\
\text { Scientific knowledge can hange } \\
\text { over time. } \\
\text { Creativity plays an important role } \\
\text { in science. } \\
\text { Background knowledge } \\
\text { influences how scientists view } \\
\text { data. }\end{array}$ \\
\hline
\end{tabular}

Fig. 1. Three Domains of Science [2]. 
Since physics constitutes science, we can think analogically that the nature of physics has something in common with the nature of science, that is, the nature of physics as product (knowledge), physics as attitude (way of thinking), and physics as process (way of investigating). On the nature of physics as product, the pile of knowledge can be facts, concepts, priciples, laws, formulas, theory, and model. Physics as process has the following indicators: observing, clasifying, measuring, questioning, hyphotizing, planning investigating/experiments, interpreting, and communicating. Meanwhile, physics as attitude has the following indicators: curiousity, emphaty, responsibility, honesty, open minded, and cooperation (Sutrisno).

The nature of physics as product, process, and attitude has consequently the impact on how to teach physics in classes. Physics instruction mostly performed by teachers are commonly the manifestation of physics learning as product that is merely teaching concepts, theory, formula, etc. Thus, learning physics as attitude as well as process has not got enough attention yet.

Learning physics as a process is also important for students to comprehend and investigate principles, laws, theories, natural phenomena and their relationship. Learning physics as process consequently has relationship with the process of investigating the natural phenomena as well as the causeresponse it yields. The investigation activities include observing, classifying, measuring, questioning, hyphotesizing, planning experiment, interpreting, and communicating. These activities in physics learning are recognized as science process skills [4]. Through learning these skills students are expected to understand the nature of science, especially physics.

\section{Overview of Teaching Methods}

Teaching approaches used to develop students' understanding on the nature of science include the following: 1) learning cycle lessons taught to peers (including a reflective analysis about what was learned about science and science teaching, 2) the design and implementation of a research experiment, a written research report, and sharing of results with peers, 3) a follow-up reflective analysis of the experiment, summarizing what was learned about the nature of scientific inquiry and knowledge and how such an experiment might be structured in an elementary classroom, and 4) a quiz on the nature of science and scientific knowledge [1].

In addition to the above explanation, we should involve students in an experience which requires them to use the processes of science in the design and conducts their own research study. Students work by themselves in a group of 2-4. They are in a complete control of this experience, from the development of a research question which interests them to the formulation of a hypothesis, the design of an experiment, the collection and recording of data, the interpretation of results, and the drawing of conclusions based on their results. Students are then required to submit a written report of their work and share their results with the 'scientific community' of their peers [1].

Besides, real life scenarios are recomended to use for teaching the nature of science. Real life scenario reinforces classroom learning. The scenarios are ideal for classes of any size, but they work best when each student has access to special needed equipment. Case studies should be relevan to students as this will make it easier to engage them in learning [5].

Additionally, hands-on activities with follow-up work are also encouraged. Hands-on activities are a great way to introduce students to the world of science and excellent opportunity for learning. All hands-on activities should be followed by follow-up work, whether teachers assign an essay or ask students to complete a group project. Assignment questions should be directed to ask students to analyze the results of the activities and explain why a certain set of events may have occured. These assignments reinforce learning and help students understand scientific principles better [5].

\section{Science Process Skills}

One of the most important goals of science education is to teach students how to get involved in inquiry. In other words, students should integrate skills, knowledge, and attitudes to develop a better understanding of scientific concepts. Therefore, teachers must focus on teaching science skills such as facts, concept and theories to encourage students through scientific investigation. Science process skills are a necessary tool to produce and use scientific information, to perform scientific research, and to solve problem (Aktamis \& Ergin).

\section{1) Teaching the Science Process Skills}

There are three dimensions of science that teacher should pay attention when teaching students about science. The first is science knowledge. It is the content of science, the basic concepts, and our scientific knowledge. This is the dimension of science that most people first think about, and it is certainly very important. The second is processes of doing science. It is the science process skills that scientists use in the process of doing science. Since science is about asking questions and finding the answers to the questions, the searching is actually the same skill that we all use in our daily lives as we try to figure out everyday questions. When we teach students to use these skills in science, we are also teaching them skills that they will use in the future in every area of their live. The third dimension of science focuses on the characteristic attitudes and dispositions of science. These include such things as being curious and imaginative, as well as being enthusiastic about asking questions and solving problems. Another desirable scientific attitude is a respect for the methods and values of science. These scientific methods and values include seeking to answer questions using some kind of evidence, recognizing the importance of rechecking data, and understanding that scientific knowledge and theories change over time as more information is gathered.

\section{2) Six Basic Process Skills}

The Science Process Skills form the foundation for scientific methods. There are six basic science process skills namely observation, communication, classification, measurement, inference, and prediction. These basic skills are integrated together when scientists design and carry out experiments or in every day life when we all carry out fair test experiments. All the six basic skills are important individually 
as well as when they are integrated together. The six basic skills can be put in a logical order of increasing sophistication, although even the youngest students will use all of the skills along side one another at various times. In the earliest grades, students will spend a larger amount of time using skills such as observation and communication. As students get older they will start to spend more time using the skills of inference and prediction. Classification and measurement tend to be used across the grade levels more evenly, partly because there are different ways to do classifying in increasingly complex ways, and because methods and systems of measuring must also be introduced to children gradually over time.

Integrating the basic science process skills together and gradually developing abilities to design fair tests are increasingly emphasized in successive grade levels, and is an expectation of students by the fourth grade (www.longwood.edu ).

\section{3) Integrated Science Process Skills}

Integrated Science Process Skills include predicting, communicating, controlling variables, hypothesizing, experimenting, and data interpreting. Predicting means forecasting a future occurence based on past observation or the extension of data. While communicating means using words, symbols, or graphics to describe an object, action or event. Controlling variables is manipulating and controlling properties that relates to situations events for the purpose of determining causation. Hypothesizing is stating tentative generalization of observations or inferences that may be used to explain a relatively larger number of events but that is immediate oe eventual testing by one or more experiments. Experimentation is testing a hypothesis through the manipulation and control of independent variables and noting the effects on a dependent variable: interpreting and presenting results in the form of a report that others can follow to replicate the experiment. Data interpreting means arriving at an explanation, inference, or hypothesis from data that have been graphed or placed in a table .

\section{E. Problem Based Learning}

1) Outcome of $P B L$.

PBL model of instruction has several learning outcomes, including 1) thinking skills and problem solving. High order thinking, such as analzing, criticizing, and making conclusion based on inference and reasonable considerations are skills aimed to achieve in PBL, 2) imitation of adults. PBL is also aimed to help students take action in real life situation and learn the important role of adults, 3) independent learner. PBL strives to help students become independent learner and self regulated learner [6], 4) long life learning skills.

\section{2) Syntax of PBL}

TABLE I. SYNTAX OF PBL

\begin{tabular}{|l|l|}
\hline \multicolumn{1}{|c|}{ Phase } & \multicolumn{1}{|c|}{ Teacher Behavior } \\
\hline $\begin{array}{l}\text { Phase1: Direct students to the } \\
\text { problem. }\end{array}$ & $\begin{array}{l}\text { Teacher explains the aim of } \\
\text { instruction, describes the importance } \\
\text { logistic needs, and motivates } \\
\text { students to be involved in problem } \\
\text { solving activities. }\end{array}$ \\
\hline Phase2: Organize students to learn. & Teacher helps students define and \\
\hline
\end{tabular}

\begin{tabular}{|l|l|}
\hline & $\begin{array}{l}\text { organize learning tasks related to the } \\
\text { problem. }\end{array}$ \\
\hline $\begin{array}{l}\text { Phase 3: Help students to work } \\
\text { independently and in group } \\
\text { investigation. }\end{array}$ & $\begin{array}{l}\text { Teacher fosters students to collect } \\
\text { relevant information, perform the } \\
\text { experiment, and seek explanation } \\
\text { and solution. }\end{array}$ \\
\hline $\begin{array}{l}\text { Phase 4 : Develop and present } \\
\text { artifact and exhibition. }\end{array}$ & $\begin{array}{l}\text { Teacher helps students in planning } \\
\text { and preparing relevant (SESUAI) } \\
\text { artifact, such written report, video, } \\
\text { and model, as well as helping them } \\
\text { in collaboration. }\end{array}$ \\
\hline $\begin{array}{l}\text { Phase 5: Analyze and evaluate } \\
\text { problem solving process. }\end{array}$ & $\begin{array}{l}\text { Teacher helps students reflect the } \\
\text { investigation and the process they } \\
\text { use. }\end{array}$ \\
\hline
\end{tabular}

Source: [6]

\section{METHODS}

This reseach was aimed to investigate the difference between science process skills (SPS) before and after the implementation of PBL instruction. The students' SPS include the skills of identifying problem, formulating hypothesis, indentifying variables, planning experiments, performing experiment, organizingdata, analyzing data, and drawing conclusion.

The research was conducted at Junior High School Lukmanul Hakim, located at Jl. Perjuangan, Samarinda, East Kalimantan. The participants were the VIII grade; 8 out of 16 were chosen as the sample of the research.

The instrument used to take the data of students' science process skill was a set of students' work sheet containing questions concerning with science process skills to be answered by those students. Besides, an observation sheet was also used to get the students' data concerning with their performance in conducting the experiment.

The skills were graded with the scale of $0-5$ (for identifying problem, hyphotiszing formulation, indentifying variables) and $0-10$ for planning experiments, performing the experiment, data organizing, data analysis, and drawing conclusion, where getting 0 means the students did not answer the item addressed, and getting 5 (for identifying problem, formulating hypothesis, and indentifying variables) and 10 for planning experiments, performing the experiment, organizing data, analyzing data, and drawing conclusion means he/she answered it perfectly. This can be summarized in Table 2 .

TABLE II. MAXIMUM SCORE OF ITEMS OF SPS

\begin{tabular}{|l|l|l|}
\hline No of item & \multicolumn{1}{|c|}{ Science Process Skills } & Maximum Score \\
\hline 1 & Identifying problem & 5 \\
\hline 2 & Formulating hypothesis & 5 \\
\hline 3 & Identifying variables: & \\
& $-\quad$ Independent variable & 5 \\
& $-\quad$ Dependent variable & 5 \\
& $-\quad$ Control variable & 5 \\
\hline 4 & Planning experiment & 10 \\
\hline 5 & Performing experiment & 10 \\
\hline 6 & Organizing data & 10 \\
\hline 7 & Analyzingdata & 10 \\
\hline 8 & Drawing conclusion & 10 \\
\hline
\end{tabular}


First, the data of each component of science process skills were examined qualitatively by finding its average. These data could show what the most difficult component of science process skills for the students was. The data of science process skills of students before and after problem based learning instruction were compared using paired-t test. Similarly, the difference between science process skills before and after problem based learning instruction for each component was examined.

\section{RESULT}

The profile of the science process skills grading before and after problem based learning instruction was on Table 3 and Table 4.

TABLE III. SCIENCE PROCESS SKILLS BEFORE PBL INSTRUCTION

\begin{tabular}{|c|c|c|c|c|c|c|c|c|c|c|c|c|}
\hline \multirow{2}{*}{ No } & \multirow{2}{*}{ Name } & \multirow{2}{*}{1} & \multirow{2}{*}{2} & \multicolumn{3}{|c|}{3} & \multirow{2}{*}{4} & \multirow{2}{*}{5} & \multirow{2}{*}{6} & \multirow{2}{*}{7} & \multirow{2}{*}{8} & \multirow{2}{*}{ Tot } \\
\hline & & & & $\mathbf{a}$ & $\mathbf{b}$ & c & & & & & & \\
\hline 1 & RY & 2 & 0 & 0 & 0 & 0 & 5 & 6 & 0 & 0 & 0 & 13 \\
\hline 2 & MI & 4 & 2 & 0 & 0 & 0 & 5 & 6 & 1 & 0 & 0 & 18 \\
\hline 3 & YBS & 0 & 0 & 5 & 2 & 5 & 6 & 4 & 4 & 6 & 0 & 32 \\
\hline 4 & DR & 1 & 1 & 1 & 1 & 1 & 6 & 6 & 1 & 0 & 0 & 18 \\
\hline 5 & GA & 0 & 1 & 0 & 0 & 0 & 3 & 4 & 0 & 0 & 0 & 8 \\
\hline 6 & Adit & 3 & 5 & 4 & 2 & 1 & 7 & 6 & 3 & 4 & 0 & 35 \\
\hline 7 & DHA & 4 & 1 & 5 & 2 & 1 & 6 & 6 & 1 & 2 & 0 & 28 \\
\hline 8 & M & 3 & 1 & 1 & 3 & 2 & 5 & 4 & 4 & 0 & 0 & 23 \\
\hline & Tot & 17 & 11 & 16 & 10 & 10 & 43 & 42 & 14 & 12 & 0 & 175 \\
\hline
\end{tabular}

TABLE IV. SCIENCE Process Skills After PBL Instruction

\begin{tabular}{|c|c|c|c|c|c|c|c|c|c|c|c|c|}
\hline \multirow{2}{*}{ No } & \multirow[b]{2}{*}{ Name } & \multirow[b]{2}{*}{1} & \multirow[b]{2}{*}{2} & \multicolumn{3}{|c|}{3} & \multirow{2}{*}{4} & \multirow{2}{*}{5} & \multirow{2}{*}{6} & \multirow{2}{*}{7} & \multirow[b]{2}{*}{8} & \multirow[b]{2}{*}{ Tot } \\
\hline & & & & $\mathbf{a}$ & b & c & & & & & & \\
\hline 1 & RY & 5 & 2 & 0 & 0 & 0 & 4 & 7 & 4 & 4 & 4 & 30 \\
\hline 2 & MI & 4 & 3 & 5 & 4 & 5 & 9 & 9 & 10 & 8 & 0 & 57 \\
\hline 3 & YBS & 0 & 0 & 1 & 1 & 0 & 7 & 6 & 10 & 8 & 6 & 39 \\
\hline 4 & $\overline{D R}$ & 5 & 1 & 5 & 0 & 1 & 9 & 8 & 8 & 6 & 0 & 43 \\
\hline 5 & GA & 0 & 0 & 0 & 0 & 0 & 5 & 5 & 4 & 0 & 0 & 14 \\
\hline 6 & Adit & 4 & 4 & 5 & 2 & 1 & 8 & 9 & 10 & 10 & 8 & 61 \\
\hline 7 & DHA & 4 & 4 & 2 & 2 & 2 & 7 & 9 & 10 & 9 & 7 & 28 \\
\hline 8 & $\mathrm{M}$ & 5 & 1 & 0 & 0 & 0 & 6 & 7 & 6 & 8 & 8 & 23 \\
\hline & Tot & 27 & 15 & 18 & 9 & 9 & 55 & 60 & 62 & 53 & 33 & 341 \\
\hline
\end{tabular}

The cumulative score before the implementation of Problem Based Learning instruction for identifying problem was 17 which was $42.50 \%$ of the maximum score 40 . Then, for hypothesizing was $12.50 \%$, for identifying variables was $30 \%$. For planning experiment was $53.75 \%$, performing experiment was $52.5 \%, 17.5 \%$, data organization was $68.5 \%$, for data analysis is $15 \%$, and drawing conclusion was 0 .

The cumulative score after the implementation of Problem Based Learning instruction for identifying problem was 27 which was $67.50 \%$ of the maximum score 40 . Hypothesizing was $37.50 \%$, for identifying variables was $30 \%$, for planning experiment was $68.65 \%$, performing experiment was $75 \%$, $17.5 \%$, data organization was $77.5 \%$, for data analysis was $66.25 \%$, and drawing conclusion was 41.25 . The mean score for the science process skills before problem based learning instruction was 175 (29.17\%); while it was after problem based learning instruction was 341 or $56.83 \%$.
It means that before the implementation of PBL instruction the students did not know how to make a hypothesis, problem formulation, variables identification, design an experiment, organize data, analyze data, and draw conclusion. After the PBL instruction, their average score was better significantly in most aspects, except in identifying variable. The cumulative score for science process skills before problem based learning instruction is evaluated as a poor display of basic and integrated science process skills; while it was after problem based learning instruction was still poor, but it showed significantly better performance.

The paired t-test for the two means showed that there was significant difference between the two skills in the science process skills which was not among the priority of the traditional class as can be seen on Table 5. The teaching of these skills through the traditional lecture mode faced with problems such as time constraint. Likewise, the limited opportunity for students to participate in inquiry and hands on activities may not serve the students' need for more enhanced psychomotor development.

TABle V. PAIRED T-Test OF The MEAN SCORE IN THE SCIENCE PROCESS SKILLS

\begin{tabular}{|l|l|l|l|l|}
\hline No & \multicolumn{1}{|c|}{ Components } & \multicolumn{1}{|c|}{ T } & $\begin{array}{c}\text { T } \\
\text { table }\end{array}$ & \multicolumn{1}{|c|}{ Conclusion } \\
\hline 1 & Identifying problem & 2.4 & 2.365 & Significantly different \\
\hline 2 & Hypothesizing & 0.83 & 2.365 & $\begin{array}{l}\text { Insignificantly } \\
\text { different }\end{array}$ \\
\hline 3 & Identifying variables & $0.46 ;$ & 2.365 & $\begin{array}{l}\text { Insignificantly } \\
\text { different }\end{array}$ \\
& & $0.18 ;$ & & \\
\hline 4 & Planning experiment & 2.126 & 2.365 & Significantly different \\
\hline 5 & Performing & 7.19 & 2.365 & Significantly different \\
& experiment & & & Significantly different \\
\hline 6 & Data organization & 11.47 & 2.365 & Significantly different \\
\hline 7 & Data analysis & 5.00 & 2.365 & Significantly different \\
\hline 8 & Drawing conclusion & 3.198 & 2.365 & Signican \\
\hline
\end{tabular}

The mean score for the science process skills before problem based learning instruction is considered low. The possible cause of this unexpected score may be caused by the students who have not yet been introduced to science process skills. They used traditional instruction which was text based and lack of direct experience of experiment and not connected to daily phenomena around them.

The mean score for the science process skills after problem based learning is judged still low, but there is a significant improvement in students' science process skills. The estimated cause of this because students have had already acquainted with these skills after the PBL instruction, the prior knowledge may function as their advanced organizer to perform better, and they got enough information they needed and sufficient scaffolding by the tutor and peers.

However, there is one aspect that has not been yet improved, that is identifying variables. The suspected cause is probably that the students lack information and prior knowledge concerning with these, lack of students' prior knowledge and supporting literature, students need more 
guidance from tutor and peer, lack of students' skills and interest.

Based on the discussion of this study, the ways on how to improve PBL instruction in teaching of weight are using better material (better elasticity of elastics) and better way of measuring, prepare students with more prior knowledge and skills.

\section{CONCLUSION}

The average of science process skills of the students prior to problem based learning instruction was very low (29.17\%). The average of science process skills of the students after problem based learning instruction was low (56.83\%). The difference of average of science process skills of the students before after problem based learning instruction was significantly different.

\section{REFERENCES}

[1] Y. J. Meichtry, "The Nature of Science and Scientific Knowledg: implications for Designing a Preservice Elementary Method Course", www.csss.science.org, 2008.

[2] R. L. Bell, "Teaching the Nature of Science: Three Critical Questions", National Geographic, University of Virginia, 2009.

[3] C. A. Guavera, "Science process sklils development through innovations in science teaching", Reseach Journal of Educational Sciences vol 3(2), 2015.

[4] M. Nur, "Model Pembelajaran Berdasarkan Masalah", Pusat Sains dan Matematika Sekolah Unesa, Surabaya, 2011.

[5] E. Nova, "Teaching Techniques for Science Teachers", Edu Nova.com, 2012

[6] R. I. Arends, "Learning to Teach", McGrawHill, New York, 2012. 